\title{
AMINO ACID ACTIVATING ENZYMES IN RED BLOOD CELLS OF NORMAL, ANEMIC AND POLYCYTHEMIC SUBJECTS *
}

\author{
By G. IZAK, T. WILNER AND J. MAGER with THE technical AsSistaNce of \\ A. KARSHAI

\begin{abstract}
(From the Department of Medicine B, and the Hematology Research Laboratory of Hadassah
University Hospital and from the Department of Biochemistry, Hebrei'

University-Hadassah Medical School, Jerusalem, Israel)
\end{abstract}

(Submitted for publication May 18, 1960 ; accepted June 9, 1960)

Following the discovery by Hoagland (1) that the soluble cytoplasmic fraction of rat liver homogenates catalyzes an amino acid-dependent pyrophosphate $(\mathrm{PP})$ exchange with adenosine triphosphate (ATP), similar systems have been described in a variety of other tissues and organisms (2-4). These so-called "amino acid activating enzymes" (AAAE) serve, according to the currently prevailing opinion (5), to convert free amino acids into the corresponding aminoacyl adenylates, thus initiating the chain of reactions mediating their incorporation into the protein molecule.

The present communication provides evidence for the occurrence of AAAE in human red blood cells (RBC). In addition, the paper presents quantitative data indicating the existence of some significant deviations from the normal level of activity of these enzymes in certain well defined blood disorders.

\section{MATERIALS AND METHODS}

Blood samples. Blood was obtained by venipuncture from healthy donors and anemic or polycythemic patients. The salient hematological data are recorded in Table I.

Preparation of hemolysates. The cells from freshly drawn heparinized blood samples were sedimented by centrifugation, washed 3 times with 2 vol of physiological saline buffered with veronal, $\mathrm{pH} 7.3$, and counted before the last washing. All the subsequent operations were carried out in the cold.

Two $\mathrm{ml}$ of the packed blood cells were hemolyzed by dilution with $1.6 \mathrm{vol}$ of cold distilled water. Following 10 minutes of stirring, the isotonicity of the hemolysate was restored by adding concentrated sucrose solution to a final concentration of $0.25 \mathrm{M}$, and the volume was made up to $10 \mathrm{ml}$. Ghosts and particles were removed by spinning the hemolysate for 30 minutes at $15,000 \mathrm{G}$ in the Servall centrifuge. The resulting clear supernatant

* This work was supported by a research grant from the Hadassah Medical Organization. solution was carefully decanted and served as the source of amino acid activating enzymes. The hemolysate could be stored at $-15^{\circ} \mathrm{C}$ for at least 2 weeks without appreciable loss of activity with respect to amino acid activation. This preparation was routinely used and no attempt was made to exclude platelets and leukocytes, since the contribution of these cells to the over-all activity of the lysate was found to be negligible (see Results).

In some experiments the washed blood cells suspended in $0.25 \mathrm{M}$ sucrose were disrupted by sonication in an ice water-cooled $10 \mathrm{KC}$-Raytheon oscillator.

Chemicals. All chemicals were of analytic or reagent grade. The radioactive pyrophosphate was prepared by pyrolysis of $\mathrm{P}^{22}$-labeled orthophosphate at $280^{\circ} \mathrm{C}$ for 20 to 30 hours. The product usually contained less than 0.1 per cent orthophosphate.

Standard reaction mixture and assay procedure. Unless otherwise stated, the following reaction mixture was used for assaying amino acid activation: Tris buffer, $\mathrm{pH}$ 7.4, $50 \mu$ moles; $\mathrm{MgCl}_{2}, 5 \mu$ moles; ATP, $2 \mu$ moles; PP $2 \mu$ moles; amino acid mixture as indicated in the legend to Table II; NaF, $20 \mu$ moles; hemolysate, $0.3 \mathrm{ml}$. The volume was made up to $1 \mathrm{ml}$ with distilled water and the mixture was incubated for 20 minutes at $37^{\circ} \mathrm{C}$. The reaction was stopped by the addition of $5 \mathrm{ml}$ of 5 per cent trichloroacetic acid. The precipitated protein was removed by centrifugation, and $2 \mathrm{ml}$ samples of the clear supernates were each treated with $1 \mathrm{ml}$ of a 5 per cent suspension of acid-washed charcoal ("Norit A") in order to adsorb the ATP (8). The charcoal was washed 5 times with $\mathrm{pH} 4.5$ acetate buffer containing $10 \mu$ moles PP per ml, once with distilled water, and was then suspended in an alcohol: ether mixture $(3: 1 \mathrm{vol} / \mathrm{vol})$ and transferred quantitatively to planchets. The radioactivity was measured with an end-window Geiger-Mueller counter and the activity was calculated by dividing the total counts per minute incorporated into the ATP by the specific activity of the pyrophosphate added and expressed in terms of micromoles of $\mathrm{PP}$ exchanged per milligram protein of the homolysate or per $10^{11} \mathrm{RBC}$. Under the specified conditions the reaction closely followed a zero order course.

Analytical procedure. Total protein was determined by the method of Lowry, Rosebrough, Farr and Randall (9) and hemoglobin was estimated by the cyanmethemoglobin procedure (10). Inorganic phosphate was deter- 
TABLE I

Summary of hematological data in the various groups of patients (range)

\begin{tabular}{|c|c|c|c|c|c|c|c|}
\hline Clinical diagnosis & $\begin{array}{l}\text { No. of } \\
\text { patients }\end{array}$ & Hemoglobin & RBC* & Hematocrit & Reticulocytes & Serum iron $†$ & Vitamin $B_{12} \ddagger$ \\
\hline Normal & 30 & $\begin{array}{c}g m \% \\
13.4-15.2\end{array}$ & $\begin{array}{l}10^{6} / \mathrm{cu} \mathrm{mm} \\
4.6-5.2\end{array}$ & $\begin{array}{c}\% \\
44-49\end{array}$ & $\stackrel{\%}{0.1-0.6}$ & $\begin{array}{c}\mu g \% \\
79-108\end{array}$ & $\begin{array}{l}\mu \mu g / m l \text { serum } \\
180-420\end{array}$ \\
\hline $\begin{array}{l}\text { Macrocytic } \$ \\
\text { hyperchromic anemia }\end{array}$ & 20 & $6.5-9.2$ & $1.5-3.2$ & $21-36$ & $1.2-3.1$ & $67-110$ & $60-190$ \\
\hline $\begin{array}{l}\text { Microcytic } \\
\text { hypochromic anemia }\end{array}$ & 16 & $4.5-7.2$ & $2.7-3.9$ & $19-34$ & $0.8-2.8$ & $0-38$ & $200-450$ \\
\hline Polycythemia vera & 10 & $15.9-18.0$ & $5.7-7.5$ & $53-70$ & $0.1-1.1$ & $70-115$ & $270-390$ \\
\hline
\end{tabular}

$* \mathrm{RBC}=$ red blood cells.

+ Determined according to the method of Davies, Levin and Oberholzer (6).

$¥$ Determined according to the method of Grossowicz, Aronovitch and Rachmilewitz (7).

$\$$ No patients with pernicious anemia (lack of intrinsic factor) or aplastic anemia have been included in this group.

mined by the method of Fiske and Subbarow (11). All the experiments were run in duplicate.

\section{RESULTS}

Conditions governing $P P^{32}-A T P$ exchange in hemolysates. As shown in Table II, hemolysates prepared from normal RBC catalyzed the incorporation of $\mathrm{P}^{32}$-labeled pyrophosphate into ATP.

Omission of amino acids from the otherwise complete reaction mixture resulted in a decrease

TABLE II

$P P^{32}-A T P$ exchange in a normal blood hemolysate; requirements of the reaction *

\begin{tabular}{|c|c|c|}
\hline & 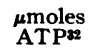 & $\underset{\text { ATP }}{\mu \text { moles }}$ \\
\hline & $\begin{array}{l}100 \mathrm{mg} \\
\text { protein }\end{array}$ & $10^{11} \mathrm{RBC}$ \\
\hline \multicolumn{3}{|l|}{ "Complete amino acid } \\
\hline Amino acid mixture "A" $\ddagger$ & 11.2 & 31.0 \\
\hline Tryptophan & 8.7 & 25.3 \\
\hline No amino acids & 5.1 & 13.7 \\
\hline No ATP & 2.1 & 4.5 \\
\hline No $\mathrm{Mg}^{++}$ & 3.8 & 6.3 \\
\hline $\mathrm{P}^{32} \mathrm{Pi} \S$ added instead of $\mathrm{PP}^{32}$ & 0 & 0 \\
\hline Pyrophosphatase added & $\mathbf{0}$ & 0 \\
\hline
\end{tabular}

* Conditions as described under Methods; see first section of text for abbreviations.

$\dagger$ Based on the red cell count performed immediately prior to lysis.

¥ "Complete amino acid mixture": arginine, aspartic, glycine, histidine, serine, isoleucine, leucine, lysine, phenylalanine, threonine, tryptophan, valine, glutamic, methionine, cysteine, tyrosine, proline. All amino acids were of the L-series and were added at $5 \times 10^{-4} \mathrm{M}$ final concentration. Amino acid mixture " $A$ ": arginine, glycine, histidine, serine, threonine, tryptophan, valine. Inorganic pyrophosphatase $(40 \mu \mathrm{g})$ was added and the reaction mixture was pre-incubated for 5 to $\mathbf{1 0}$ minutes prior $t$ io the addition of ATP. (Kindly supplied by Dr. M. Kunitz, the Rockefeller Institute for Medical Research.)

$\S \mathrm{Pi}$ : inorganic phosphate. in the rate of exchange to one-fourth to one-half of that observed with the complete system. It appeared likely that the considerable "background" activity obtained without the addition of amino acids was due to the appreciable amounts of amino acids released from the $\mathrm{RBC}$ in the course of lysis (12), especially since low substrate saturation levels are characteristic of the amino acid activating enzymes $(2,3)$. The validity of this assumption is strengthened by the finding that the ratio between

TABLE III

Precipitation of the AAAE at $p H 5.0$ in the presence of sodium ribonucleate ${ }^{*}$

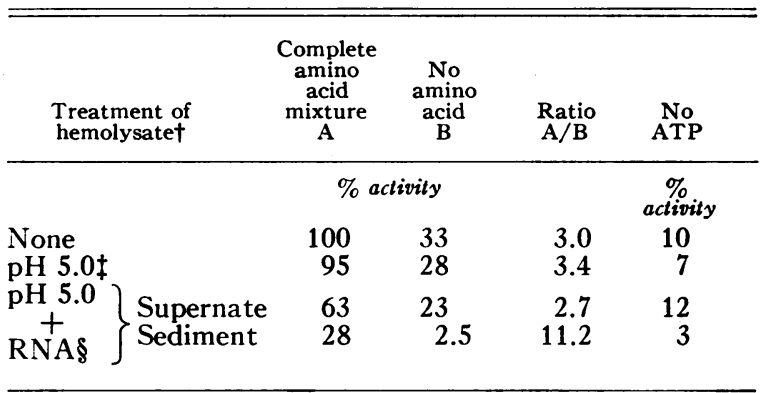

* The results are expressed in percentage of the activity obtained with untreated hemolysate, the latter set at 100 per cent. See footnotes ${ }^{*}$ and $\ddagger$ to Table II for definitions. $\dagger$ Hemolysate: particle-free supernate prepared from whole blood as described under Methods.

$\ddagger$ The $\mathrm{pH}$ of the ice-chilled hemolysate was lowered to 5.0 by dropwise addition of $1 \mathrm{~N}$ acetic acid with continuous stirring. No precipitate was obtained. The $\mathrm{pH}$ of the hemolysate was immediately readjusted with $1 \mathrm{~N}$ Tris buffer to 7.2.

$\S \mathrm{pH} 5.0+\mathrm{RNA}: 30 \mathrm{mg} / \mathrm{ml}$ sodium ribonucleate [commercial yeast, RNA, purified according to the procedure of Woodward (13)] was added to the hemolysate with stirring until dissolved. Thereafter the solution was treated as above. The precipitate formed at $\mathrm{pH} 5.0$ was sedimented by centrifugation and dissolved in a measured quantity of Tris buffer, $0.025 \mathrm{M}, \mathrm{pH} \mathrm{7.2}$. The $\mathrm{pH}$ of the supernate was readjusted as above. 
the endogenous and the amino acid-stimulated $\mathrm{PP}^{32}$-ATP exchange activity increased from $1: 3$ in the crude hemolysate to $1: 11$ in a fraction of this hemolysate isolated by $\mathrm{pH}$ precipitation (Table III).

By examining various amino acids singly and in combination, it was found that amino acid mixture "A" (see legend to Table II) enhanced the exchange rate almost to the same extent as did a mixture of 18 natural amino acids, whereas 80 per cent of the maximal effect was elicited by tryptophan alone.

The radioactivity yielded without added ATP was about 15 per cent of that obtained with the complete reaction mixture. These counts could be almost entirely eliminated by using an isolated fraction of the hemolysate, indicating that this residual activity was due to the endogenous ATP content of the hemolysate (Table III).

Omission of $\mathrm{Mg}^{++}$resulted in a roughly 70 per cent drop of the reaction rate (Table II).

$\mathrm{P}^{32}$-orthophosphate failed to induce any detectable exchange with ATP when substituted for $\mathrm{PP}^{32}$ in the standard reaction mixture. The specificity of the system with respect to pyrophosphate was even more convincingly demonstrated by the finding that crystalline inorganic pyrophosphatase completely abolished the exchange reaction (Table II).

The $\mathrm{pH}$ of optimum $\mathrm{PP}^{32}$-ATP exchange activity was found to range from 6.1 to 7.3. By varying the concentration of the amino acids in the reaction mixture the maximal rate of exchange was attained at levels close to $2 \times 10^{-4} \mathrm{M}$.

The considerable adenosine triphosphatase and pyrophosphatase activity of the lysates, as measured by the release of orthophosphate from the respective substrates in the course of incubation, was entirely eliminated by the fluoride included in the reaction mixture. The stability of the assay system was also borne out by the fact that the rate of exchange remained practically constant during an experimental period which lasted for at least 40 minutes (Table IV).

Identification of the reaction product. At the end of the reaction the labeled ATP was adsorbed onto charcoal and the residual $\mathrm{PP}$ was removed by extensive washing. Thereafter the ATP was eluted with 50 per cent ethanol containing $0.5 \mathrm{M}$ ammonia and isolated by paper electrophoresis,
TABLE IV

Rate of $P P^{32}-A T P$ exchange determined after increasing lengths of incubation in normal and polycythemic blood hemolysates *

\begin{tabular}{ccc}
\hline \hline \multirow{2}{*}{$\begin{array}{c}\text { Incubation } \\
\text { time }\end{array}$} & \multicolumn{2}{c}{ Rate of exchange } \\
\cline { 2 - 3 } & Normal & Polycythemic \\
\hline min & mumoles $/$ hr $/$ mg & protein \\
10 & 35.4 & 24.9 \\
20 & 35.4 & 21.6 \\
30 & 33.0 & \\
45 & 36.0 & 23.1
\end{tabular}

* Rate of exchange $(R)$ was calculated according to the following equation (14):

$$
R=\frac{(\mathrm{ATP}) \times\left(\mathrm{PP}^{32}\right)}{(\mathrm{ATP})+\left(\mathrm{PP}^{32}\right)} \times \frac{2.3}{\mathrm{t}} \times \log \frac{100}{100-\% \text { exchange }} .
$$

Conditions as in Table II. Amino acid mixture " $\mathrm{A}$ " was used.

using $0.005 \mathrm{M}$ citrate of $\mathrm{pH} 3.5$ as the mobile phase. Under these conditions radioactivity was detectable only in the ATP spot located by its quenching of ultraviolet light. When the labeled ATP was hydrolyzed with $1 \mathrm{~N} \mathrm{HCl}$ in a boiling water bath for 10 minutes, the radioactivity was no longer adsorbable with charcoal. The latter result indicated, therefore, that the $\mathrm{P}^{32}$-label was entirely confined to the acid-labile terminal pyrophosphate moiety of ATP.

Fractionation. The AAAE of the rat liver cytoplasmic fraction are referred to by Hoagland, Keller and Zamecnik (15) as pH 5.0 enzymes because of their precipitating property at this $\mathrm{pH}$ as a nucleoprotein complex. The same procedure applied to whole blood hemolysates failed to produce a precipitate without affecting, however, the activity, provided that the $\mathrm{pH}$ was quickly readjusted to neutrality. It appeared likely that this difference in behavior is attributable to the virtual

TABLE V

Distribution of amino acid activating enzymes in various formed elements of the peripheral blood *

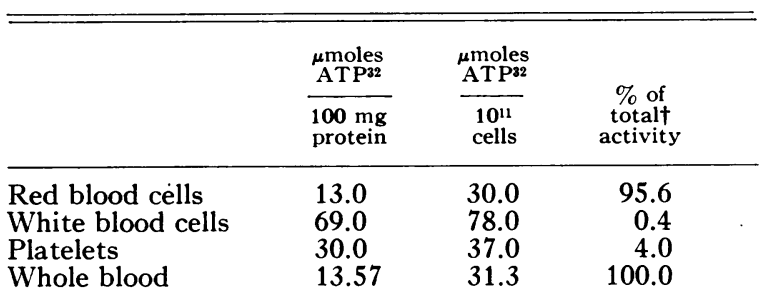

* Conditions as described under Methods.

$\dagger$ The activity of the whole blood hemolysate was set at 100 per cent. 
TABLE VI

Mean values of $P P^{32}-A T P$ exchange in blood lysates from normal subjects and from anemic and polycythemic patients

\begin{tabular}{|c|c|c|c|c|c|c|c|c|c|c|c|c|c|c|c|c|}
\hline & \multicolumn{4}{|c|}{ Normal } & \multicolumn{4}{|c|}{ Macrocytic anemia } & \multicolumn{4}{|c|}{ Microcytic anemia } & \multicolumn{4}{|c|}{ Polycythemia } \\
\hline & \multirow{2}{*}{\multicolumn{2}{|c|}{$\begin{array}{c}\mu \text { moles AT } \mathrm{A}^{32} \\
\begin{array}{l}100 \mathrm{mg} \\
\text { protein }\end{array} \\
\end{array}$}} & \multirow{2}{*}{\multicolumn{2}{|c|}{$\begin{array}{c}\mu \text { moles ATP } \\
10^{11} \mathrm{RBC} \\
\end{array}$}} & \multirow{2}{*}{\multicolumn{2}{|c|}{$\begin{array}{l}\mu \text { moles } \mathrm{ATP}^{32} \\
\begin{array}{l}100 \mathrm{mg} \\
\text { protein }\end{array} \\
\end{array}$}} & \multirow{2}{*}{\multicolumn{2}{|c|}{$\frac{\mu \text { moles ATP }{ }^{32}}{10^{11} \mathrm{RBC}}$}} & \multirow{2}{*}{\multicolumn{2}{|c|}{$\begin{array}{c}\mu \text { moles } \mathrm{ATP}^{32} \\
100 \mathrm{mg} \\
\text { protein } \\
\end{array}$}} & \multirow{2}{*}{\multicolumn{2}{|c|}{$\frac{\mu \text { moles ATP }}{32}$}} & \multirow{2}{*}{\multicolumn{2}{|c|}{$\begin{array}{c}\mu \text { moles AT } 32 \\
\begin{array}{c}100 \mathrm{mg} \\
\text { protein }\end{array} \\
\end{array}$}} & \multirow{2}{*}{\multicolumn{2}{|c|}{$\frac{\mu \text { moles ATP }}{32}$}} \\
\hline & & & & & & & & & & & & & & & & \\
\hline & Mean & $\mathrm{SD}$ & Mean & $\mathrm{SD}$ & Mean & SD & Mean & SD & Mean & SD & Mean & $\mathrm{SD}$ & Mean & $\mathrm{SD}$ & Mean & $\mathrm{SD}$ \\
\hline$\underset{\text { mixture "A"* }}{\text { Amino acid }}$ & 10.6 & 3.0 & 31.0 & 6.8 & 17.8 & 4.7 & 42.3 & 6.6 & 24.4 & 5.3 & 50.0 & 14.5 & 6.9 & 1.1 & 15.3 & 3.2 \\
\hline Tryptophan & 8.1 & 1.9 & 24.9 & 6.2 & 14.4 & 4.6 & 35.0 & 7.3 & 20.0 & 5.2 & 40.0 & 10.2 & 7.0 & 2.1 & 15.6 & 4.7 \\
\hline No amino acids & 4.5 & 1.4 & 12.3 & 2.7 & 7.5 & 2.1 & 18.3 & 4.4 & 8.0 & 1.5 & 14.1 & 4.1 & 2.9 & 0.4 & 6.7 & 1.3 \\
\hline No ATP & 2.0 & 0.8 & 5.0 & 2.0 & 2.1 & 0.5 & 6.0 & 1.5 & 1.9 & 0.6 & 3.5 & 1.5 & 1.2 & 0.2 & 2.7 & 0.4 \\
\hline
\end{tabular}

* Amino acid mixture "A"; see footnoteł to Table II. Conditions otherwise as in Table II.

absence of nucleic acids in the hemolysate. This seems to be confirmed by the finding that when RNA was added to the hemolysate, a precipitate was obtained at $\mathrm{pH} 5.0$ which contained about 25 per cent of the total AAAE activity present in the original hemolysate (Table III). No further fractionation was attempted.

The distribution of $A A A E$ in the peripheral blood cells. The distribution of the AAAE in the various formed elements of the peripheral blood was studied by determining the $\mathrm{PP}^{32}$-ATP exchange in lysates prepared separately from erythrocytes, leukocytes and platelets isolated by a modification of a conventional technique (16). As evident from Table $\mathrm{V}$, the bulk of the total blood cell activity resides in the RBC. On the other hand, the specific activity of the lysates calculated per unit number of cells is highest in the leukocytes and lowest in the RBC.

Leukocytes and $\mathrm{RBC}$ injured by a single hypotonic treatment retained about as much activity as that released into the supernatant solution. The residual activity could be solubilized by subjecting the ghosts resedimented by centrifugation to repeated osmotic lysis or to sonication for 2 to 3 minutes. On the other hand, ghosts of platelets obtained after a single hypotonic lysis exhibited no detectable $\mathrm{PP}^{32}$-ATP exchange. It may be pointed out in this connection that no $\mathrm{PP}^{32}-\mathrm{ATP}$ exchange could be demonstrated with any of the

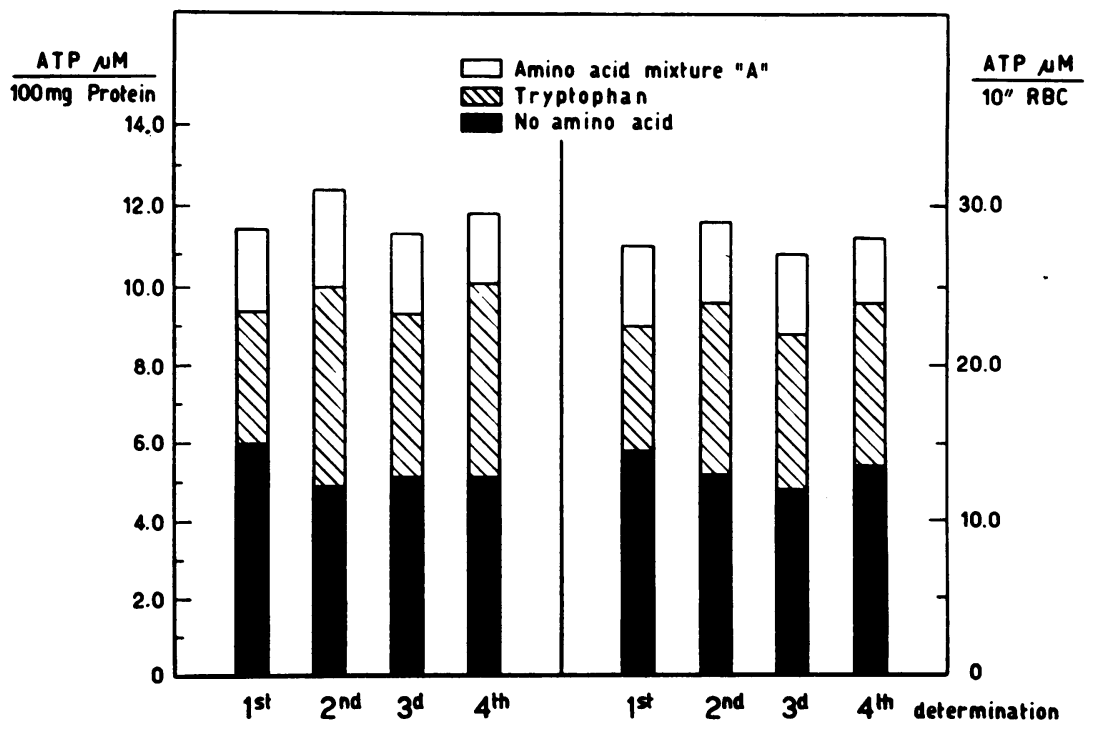

Fig. 1. Repeated determinations of $P^{32}$-ATP exchange at biweekly INTERVALS. 


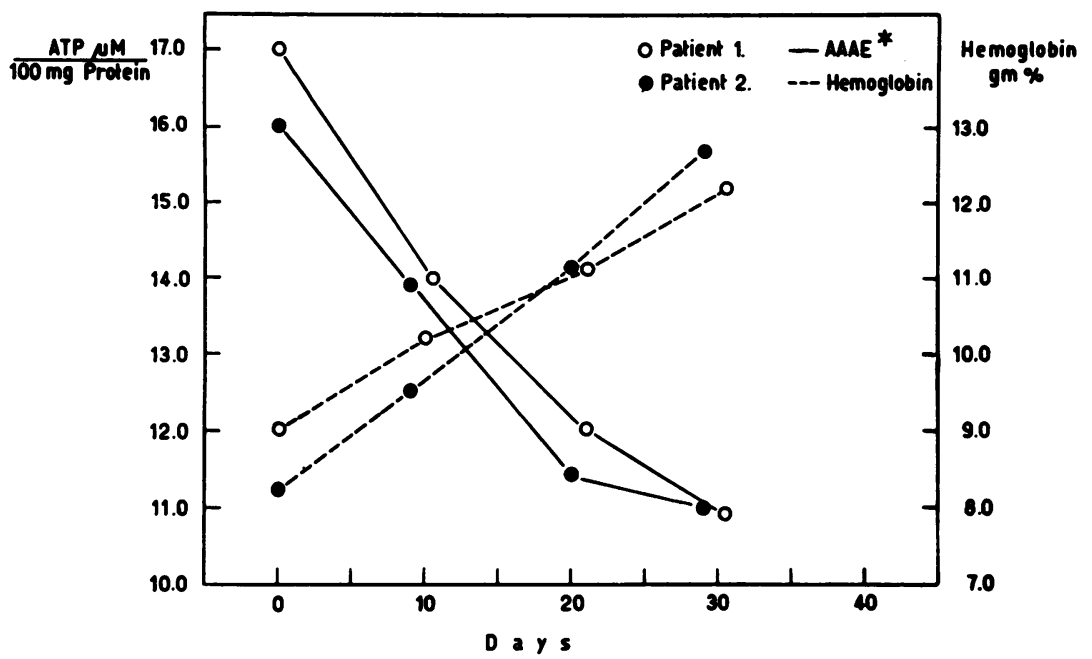

Fig. 2. GRadual decrease of PP $P^{32}$-ATP EXChaNGE PARAlleling the INCREASE in hemoglobin values in two anemic patients. * Amino acid activating enzyme.

intact cells of the peripheral blood, apparently owing to their impermeability to ATP.

Amino acid activation capacity of normal blood hemolysates. Table VI summarizes the results of a series of determinations of $\mathrm{PP}^{32}$-ATP exchange performed on blood cell hemolysates from 30 normal individuals. There was a considerable variation in the values obtained in different persons. However, when repeated determinations were made on the same subject at definite time intervals, the levels of activity were found to be remarkably constant (Figure 1).

Macrocytic and microcytic anemias. Patients with macrocytic anemia were selected from a large group of women diagnosed as anemic during pregnancy and postpartum, while cases with uncomplicated hypochromic iron deficiency anemia were chosen from subjects available at the Hematology Outpatient Department of the Hadassah University Hospital. In both groups the amino acid-dependent pyrophosphate exchange was markedly higher than the average values observed in the normal group, the increase being particularly striking in the hypochromic anemia patients (Table VI). The significance of this correlation between the biochemical alteration and the patho-

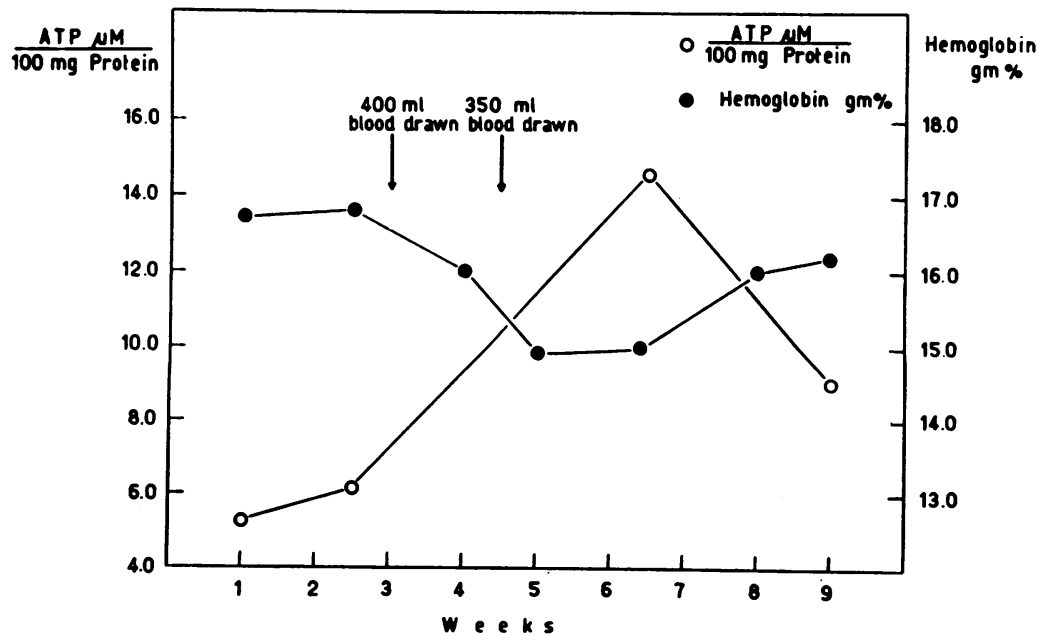

Fig. 3. INCREASE OF PP $P^{32}$-ATP EXCHANGE FOLLOWING REPEATED VENISECTIONS IN A POLYCYTHEMIC PATIENT. 
logical condition is further borne out by the follow-up of six treated patients in whom progressive decline of activity down to the normal range paralleled the improvement in the hematological status. Two representative cases are illustrated in Figure 2.

Polycythemia vera. In untreated patients with polycythemia vera the pyrophosphate exchange was of a considerably lower order than in normal subjects. Addition of tryptophan alone to the reaction mixture elicited maximal response which was not increased by further addition of other amino acids (Table VI). In these patients the activity rose substantially after repeated venesections, gradually returning, however, to the original low level within several weeks following the last phlebotomy (Figure 3).

Osmotic fragility and $A A A E$. The high activity found in anemic patients suggested the possibility that the elevated values were due to a "shift to the left" in the age of the red cell population in view of the shortened RBC life span characterizing these conditions $(17,18)$. This possibility was explored by examining the enzymic activity as a function of the osmotic fragility which is known to vary directly with the age of the red cells (19).

Table VII shows that the activity per unit number of red cells lysed remained roughly constant. The anemic cells showed an essentially similar behavior. It may be relevant to mention in this context that there was no correlation between the degree of reticulocytosis and the $\mathrm{PP}^{32}$-ATP exchange activity in the various groups studied. Thus the AAAE exhibits a uniform pattern of distribution in the RBC population, differing in

$P P^{32}-A T P$ exchange in relation to osmotic fragility

\begin{tabular}{|c|c|c|c|c|}
\hline \multirow[b]{2}{*}{$\begin{array}{c}\% / \% \\
\mathrm{NaCl} \\
\text { solution }\end{array}$} & \multicolumn{2}{|c|}{ Normal } & \multicolumn{2}{|c|}{$\begin{array}{l}\text { Microcytic hypo- } \\
\text { chromic anemia }\end{array}$} \\
\hline & $\begin{array}{c}\% \\
\text { Activ- } \\
\text { ity in } \\
\text { supernate }\end{array}$ & $\begin{array}{c}\% \\
\text { Hemo- } \\
\text { globin } \\
\text { in } \\
\text { supernate }\end{array}$ & $\begin{array}{c}\% \\
\text { Activ- } \\
\text { ity in } \\
\text { supernate }\end{array}$ & $\begin{array}{c}\% \\
\text { Hemo- } \\
\text { globin } \\
\text { in } \\
\text { supernate }\end{array}$ \\
\hline 0.4 & 30 & 39 & 14 & 17 \\
\hline 0.35 & 90 & 92 & 60 & .51 \\
\hline \multirow[t]{2}{*}{0.30} & 95 & 9.3 & 90 & 84 \\
\hline & $100^{*}$ & 100 & 100 & 100 \\
\hline
\end{tabular}

* The values obtained after lysis with distilled water are arbitrarily considered as 100 per cent. this respect from the behavior of some other enzymes, as described by Marks, Johnson, Hirschberg and Banks (20).

\section{DISCUSSION}

The occurrence of amino acid activating enzymes in mature red blood cells which are known to be incapable of protein production is surprising in view of the presumed essential role of these enzymes in the biosynthesis of protein (5). It is possible, of course, that the AAAE perform in the mature $\mathrm{RBC}$ a different function which remains to be elucidated. It is likewise conceivable, however, that the system concerned represents a nonfunctional rudiment carried over from the nucleated stages of erythropoiesis.

The pronounced differences in the AAAE activity observed between blood cells from normal subjects and those from patients with various hematological disorders seem to reflect early disturbances occurring at some stage of the RBC maturation rather than a change in the type of the mature blood cells. The uniform distribution of this activity within the blood cell population, regardless of the differences in the osmotic fragility in both normal subjects and anemic patients, indicates a lack of correlation between the level of AAAE and the age of RBC. This conclusion is also in line with the observation that the reticulocyte count did not seem to affect significantly the activity observed within a given group.

The nature of the biochemical lesion responsible for the observed deviations from the normal level of activity is not clear. It is tempting to speculate that the enhanced AAAE activity found in the anemic disorders described manifests an attempt of the hematopoietic system to compensate for the deficient hemoglobin synthesis. This hypothesis would also account for the gradual decrease of the activity, down to normal values, occurring some time after a normal hemoglobin level had been attained. On the other hand, the decrease in the AAAE level observed in patients with polycythemia vera may reflect an opposite tendency, aimed to restrain the excessive activity of the erythropoietic tissue. It is interesting to mention in this connection that the AAAL activity determined in the RBC of a limited number of patients with secondary polycythemia was found to 
be within the normal range. As to the transient increase of the $\mathrm{PP}^{32}$-ATP exchange observed in polycythemic patients following repeated venesections, this represents a response of the protein synthesizing system to the drastic reduction in the circulating red cell mass.

Thus the mechanisms discussed above can be viewed as two facets of a homeostatic device operating through a restrictive effect exerted by the red cell proteins on the formation of the enzymic system mediating their own biosynthesis. No information is available as to the nature of the regulatory factor $(\mathrm{s})$ involved in this mechanism.

Further work is required to test the validity of this interpretation.

\section{SUMMARY}

Human whole blood hemolysates were found to catalyze an amino acid-dependent exchange of pyrophosphate with adenosine triphosphate. Out of a number of amino acids tested, tryptophan showed highest activity, amounting to about 80 per cent of the total exchange rate elicited by a mixture of 18 natural amino acids. Magnesium ions proved to be an essential component of the reaction.

Other factors influencing the reaction rate, such as amino acid concentration and $\mathrm{pH}$ optimum, were determined. The product of the exchange reaction was characterized as adenosine triphosphate labeled in the two terminal phosphate groups.

The bulk of the total amino acid activating enzyme content of the hemolysates was present in the red blood cells, while leukocytes showed the highest specific activity. The distribution of these enzymes in the red blood cell population showed no correlation with its osmotic fragility pattern.

The level of amino acid activating enzyme in erythrocytes derived from patients with macrocytic and microcytic anemias was markedly increased as compared with normal values. On the other hand, a significant decrease of this activity was observed in red cells obtained from patients with polycythemia vera. These elevations above the normal range tencled to regress parallel with hematological improvement.

The significance of these enzymes in mature red cells and the possible mechanism underlying the deviations from the normal level in various hematologic disorders are discussed.

\section{REFERENCES}

1. Hoagland, M. B. An enzymic mechanism for amino acid activation in animal tissues. Biochim. biophys. Acta 1955, 16, 288.

2. DeMoss, J. A., and Novelli, G. D. An amino acid dependent exchange between inorganic pyrophosphate and ATP in microbial extracts. Biochim. biophys. Acta 1955, 18, 592.

3. Davies, E. W., Konigsberger, V. V., and Lipmann, F. The isolation of a tryptophan-activating enzyme from pancreas. Arch. Biochem. 1956, 65, 21.

4. Mager, J., and Lipmann, F. Amino acid incorporation and the reversion of its initial phase with cellfree tetrahymena preparations. Proc. nat. Acad. Sci. (Wash.) 1958, 44, 305.

5. Lipmann, F., Hülsmann, W. C., Hartmann, G., Boman, H. G., and Acs, G. Amino acid activation and protein synthesis. J. cell. comp. Physiol. 1959, 54, 75.

6. Davies, G., Levin, B., and Oberholzer, V. G. The microestimation of serum iron and unsaturated iron-binding capacity in normals and in disease. J. clin. Path. 1952, 5, 312.

7. Grossowicz, N., Aronovitch, J., and Rachmilewitz, M. Determination of vitamin $B_{12}$ in human serum by a mutant of Escherichia coli. Proc. Soc. exp. Biol. (N. Y.) 1954, 87, 513.

8. Crane, R. K., and Lipmann, F. The effect of arsenate on aerobic phosphorylation. J. biol. Chem. 1953, 201, 235.

9. Lowry, O. H., Rosebrough, N. J., Farr, A. L., and Randall, R. J. Protein measurement with Folin phenol reagent. J. biol. Chem. 1951, 193, 265.

10. Duchateau, N. J. A comparative study of oxyhemoglobin and cyanmethemoglobin determinations by photometric and spectrophotometric methods. Amer. J. med. Technol. 1957, 23, 17.

11. Fiske, C. H., and Subbarow, Y. The colorimetric determination of phosphorus. J. biol. Chem. 1925, 66, 375 .

12. Behrendt, H. J. Chemistry of Erythrocytes: Clinical Aspects. Springfield, Ill., Charles C Thomas, 1957, p. 58 .

13. Woodward, G. E. The ribonuclease activity of Pasteurella pestis (Plague Bacillus). J. biol. Chem. 1944, 156, 143.

14. Duffield, R. B., and Calvin, M. The stability of chelate compounds, III. Exchange reactions of copper chelate compounds. J. Amer. chem. Soc. 1946, 68, 557.

15. Hoagland, M. B., Keller, E. B., and Zamecnik, P. C. Enzymatic carboxyl activation of amino acids. J. biol. Chem. 1956, 218, 345. 
16. Nelken, D., Gilboa, N. (Garber) and Gurevitch, J. A method for the simultaneous separation of human thrombocytes and leukocytes. J. clin. Path. In press.

17. Scott, J. M., and Govan, A. B. Anaemia simulating pre-eclamptic toxaemia. J. Obstet. Gynaec. Brit. Emp. 1949, 56, 27.

18. Fairley, N. H., Bromfield, R. J., Foy, H., and Kondi, A. Nutritional macrocytic anaemia in Macedonia; preliminary report. Trans. roy. Soc. trop. Med. Hyg. 1938, 32, 132.

19. Chalfin, D. Differences between young and mature rabbit erythrocytes. J. cell. comp. Physiol. 1956, 47, 215.

20. Marks, P. A., Johnson, A. B., Hirschberg, E., and Banks, J. Studies on the mechanism of aging of human red blood cells. Ann. N. Y. Acad. Sci. 1958, 75, 95. 